\title{
PENGARUH KOMUNIKASI DAN LINGKUNGAN KERJA TERHADAP KINERJA PEGAWAI BADAN PERENCANAAN PEMBANGUNAN DAERAH KABUPATEN SUKOHARJO DENGAN MOTIVASI SEBAGAI VARIABEL INTERVENING
}

\author{
Sundari \\ sundari@stmikdb.ac.id \\ Antin Okfitasari \\ antin_okfitasari@stmikdb.ac.id \\ STMIK Duta Bangsa Surakarta
}

\begin{abstract}
The purpose of this study was to test the significance of the influence of communication, work environment on employee performance Regional Planning Agency Sukoharjo with motivation as an intervening variable. The population in this study were employees of the Regional Development Planning Agency Sukoharjo. The sample in this study all employees. Data used in the study is primary data taken with a list of statements given to all employees. The analysis tools used are validity, reliability testing, linearity test, path analysis, $t$ test, $F$ test, test and correlation coefficient of determination. Individual testing of the hypothesis showed that communication variables, working environment and significant positive effect on employee motivation. Variable communication, working environment and motivation positive and significant impact on employee performance. Together - each variable communication, working environment and motivation positive and significant impact on the performance variables. Direct influence on the performance of communication larger than the indirect effect of communication on performance through motivation. Motivation in mediating the relationship between communication with ineffective performance. Direct influence on the performance of the work environment is greater than the indirect effect of work environment on performance through motivation. Motivation in mediating the relationship between work environment with ineffective performance. Because motivation is not effective in mediating the relationship between communication and performance of the work environment with motivation serve as independent variables.
\end{abstract}

Keywords : communication, work environment, motivation, performance

PENDAHULUAN.

\section{Latar Belakang Masalah}

Kinerja pegawai dapat dipengaruhi beberapa faktor antara lain kepemimpinan, kompensasi, komunikasi, lingkungan kerja, pemberian motivasi dan kepuasan kerja pegawainya. Jika salah satu faktor yang dapat mempengaruhi kinerja kurang diperhatikan akan menyebabkan kurangnya kinerja pegawai pada instansi tersebut.
Faktor-faktor kinerja yang kurang diperhatikan dalam peningkatan kinerja pegawai di Badan Perencanaan Pembangunan Daerah Kabupaten Sukoharjo antara lain komunikasi, lingkungan kerja dan motivasi. Dalam hal komunikasi kurangnya koordinasi antar bidang dalam melaksanakan kegiatan sehingga sering terjadi over lapping kegiatan antar bidang. 
Masalah lingkungan kerja, penataan peralatan kerja di tiap ruangan kurang diperhatikan. Dokumen belum disimpan dengan rapi, masih menumpuk diatas meja kerja sehingga pegawai kurang leluasa bekerja di meja kerjanya selain itu juga menyebabkan ruangan terkesan sempit, Air Conditioner yang berada di tiap ruangan tidak semua berfungsi dengan baik, hal ini membuat ruangan terasa panas sehingga beberapa pegawai kurang nyaman berada di ruang kerja dalam waktu yang lama.

Motivasi dari pimpinan juga masih kurang. Hal ini dirasakan karena ada beberapa kegiatan di bidang koordinasi yang selesai tidak tepat waktu sehingga mempengaruhi penyusunan laporan tahunan.

\section{Perumusan Dan Pembatasan Masalah}

1. Perumusan Masalah.

Berdasarkan latar belakang masalah tersebut diatas, maka dalam penelitian ini dapat dirumuskan masalah sebagai berikut :

a. Apakah komunikasi berpengaruh positif dan signifikan terhadap motivasi pegawai Badan Perencanaan Pembangunan Daerah Kabupaten Sukoharjo?

b. Apakah lingkungan kerja berpengaruh positif dan signifikan terhadap motivasi pegawai Badan Perencanaan Pembangunan Daerah Kabupaten Sukoharjo?

c. Apakah komunikasi berpengaruh positif dan signifikan terhadap kinerja pegawai Badan Perencanaan Pembangunan Daerah Kabupaten Sukoharjo?

d. Apakah lingkungan kerja berpengaruh positif dan signifikan terhadap kinerja pegawai Badan Perencanaan Pembangunan Daerah Kabupaten Sukoharjo?

e. Apakah motivasi berpengaruh positif dan signifikan terhadap kinerja pegawai Badan Perencanaan Pembangunan Daerah Kabupaten Sukoharjo?

2. Batasan Masalah
Agar pembahasan penelitian ini tidak terlalu luas dan jelas batasan yang akan diteliti, maka terdapat pembatasan masalah sebagai berikut :

a. Penelitian ini bersifat statistik kuantitatif yaitu membuat analisis perhitungan berdasarkan data yang diperoleh dari penyebaran kuisioner dan mendiskripsikan secara sistematis dan aktual fenomena yang dikaji.

b. Variabel yang dikaji dari beberapa bidang di Badan Perencanaan Pembangunan Daerah Kabupaten Sukoharjo yaitu kinerja, motivasi, komunikasi dan lingkungan kerja.

\section{Tujuan Dan Mafaat Penelitian Tujuan Penelitian}

Penelitian ini bertujuan untuk mengetahui :

a. Pengaruh komunikasi terhadap motivasi pegawai Badan Perencanaan Pembangunan Daerah Kabupaten Sukoharjo.

b. Pengaruh lingkungan kerja terhadap motivasi pegawai Badan Perencanaan Pembangunan Daerah Kabupaten Sukoharjo.

c. Pengaruh komunikasi terhadap kinerja pegawai Badan Perencanaan Pembangunan Daerah Kabupaten Sukoharjo.

d. Pengaruh lingkungan kerja terhadap kinerja pegawai Badan Perencanaan Pembangunan Daerah Kabupaten Sukoharjo.

e. Pengaruh motivasi terhadap kinerja pegawai Badan Perencanaan Pembangunan Daerah Kabupaten Sukoharjo.

\section{Kegunaan Penelitian}

a. Manfaat Teoritis

Hasil penelitian ini dapat memberikan sumbangan yang bermanfaat bagi pengembangan disiplin ilmu atau teori manajemen sumber daya manusia dan dapat dijadikan bahan acuan bagi peneliti selanjutnya, terutama yang 
berkenaan dengan komunikasi, lingkungan kerja dan motivasi terhadap kinerja pegawai.

b. Manfaat Praktis

Hasil penelitian ini dapat digunakan sebagai bahan masukan Pemerintah Daerah Kabupaten Sukoharjo dalam rangka peningkatan kinerja sumber daya manusia khususnya bagi Badan Perencanaan Pembangunan Daerah Kabupaten Sukoharjo.

\section{LANDASAN TEORI}

\section{Kinerja}

Menurut pendapat Mangkunegara, Sedarmayanti dan Mahsun dapat disimpulkan bahwa kinerja adalah catatan keberhasilan suatu pekerjaan yang telah dicapai pegawai sesuai tanggungjawabnya selama kurun waktu tertentu.

2. Motivasi

$\begin{array}{rrr}\text { Menurut } & \text { pendapat Gibson, } \\ \text { Bernard dan Samsudin dapat }\end{array}$

disimpulkan bahwa motivasi adalah kekuatan yang mempengaruhi atau mendorong seseorang untuk melakukan tindakan dalam mencapai suatu tujuan tertentu dalam organisasi.

\section{Komunikasi}

Menurut pendapat Hasibuan, Laswell dan Hovland dapat disimpulkan bahwa komunikasi adalah segala bentuk interaksi seseorang dengan yang lain dengan menggunakan bahasa untuk menyampaikan pikiran atau perasaan.

\section{Lingkungan Kerja}

Menurut pendapat Nitisemito, Sedarmayanti dan Steers dapat disimpulkan bahwa lingkungan kerja adalah segala sesuatu yang ada disekitar pegawai baik secara fisik atau non fisik yang mempengaruhi pegawai dalam melaksanakan tugasnya.

\section{Kerangka Konseptual}

Dalam penelitian ini dapat dibangun kerangka konseptual sebagai berikut :

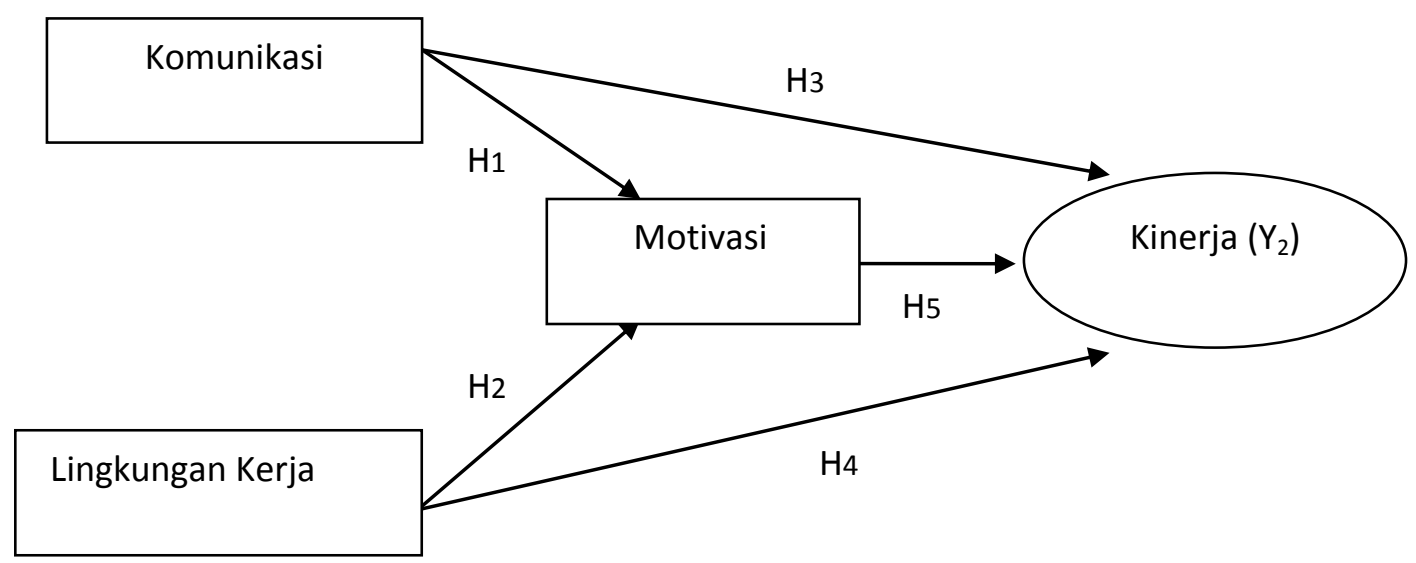

\section{METODOLOGI}

\section{Lokasi Dan Objek Penelitian}

Penelitian ini mengambil lokasi pada

Badan Perencanaan Pembangunan Daerah Kabupaten Sukoharjo yang beralamat di Jalan Jenderal Sudirman No. 199 Sukoharjo, telepon (0271) 593182.
Obyek dalam penelitian ini adalah seluruh para pegawai di Badan Perencanaan Pembangunan Daerah Kabupaten Sukoharjo yang berjumlah 34 orang.

Variabel Penelitian

Variabel bebas (independent
variable) adalah variabel yang


mempengaruhi $(\mathrm{X}), \quad$ variabel terikat (dependent variable) adalah variabel yang dipengaruhi (Y). Variabel bebas dalam penelitian ini adalah komunikasi $\left(\mathrm{X}_{1}\right)$ dan lingkungan kerja $\left(\mathrm{X}_{2}\right)$. Sedangkan variabel terikat dalam penelitian ini adalah kinerja $\left(\mathrm{Y}_{2}\right)$. Variabel intervening adalah variabel penyela atau antara yang terletak diantara variabel independen dan dependen, sehingga variabel independen tidak langsung mempengaruhi timbulnya variabel dependen. Variabel antara atau variabel intervening dalam penelitian ini adalah motivasi $\left(\mathrm{Y}_{1}\right)$.

\section{Populasi Dan Sampel Penelitian}

\section{Populasi}

Dalam penelitian ini yang menjadi populasi penelitian adalah para pegawai di Badan Perencanaan Pembangunan Daerah Kabupaten Sukoharjo yang jumlah pegawai 34 Orang yang terdiri dari 18 laki-laki dan 16 wanita.

2. Sampel Penelitian

Sampel dalam penelitian ini adalah seluruh pegawai pada Badan Perencanaan Pembangunan Daerah Kabupaten Sukoharjo yang berjumlah 34 orang.

\section{Jenis Data Dan Metode Pengumpulan Data.}

1. Data Penelitian

Data primer yaitu data yang bersumber dari tanggapan melalui kuisioner tentang kinerja, motivasi, komunikasi dan lingkungan kerja yang diisi oleh pegawai Badan Perencanaan Pembangunan Daerah Kabupaten Sukoharjo.

Data sekunder yaitu data yang diperoleh secara tidak langsung oleh peneliti yang diambil dari studi pustaka seperti literatur atau sumber-sumber lain yang ada hubunganya dengan masalah yang dibahas.
2. Metode Pengumpulan Data

Metode pengumpulan data yang akan digunakan dalam penelitian ini adalah :
a. Dokumentasi
b. Kuisioner

\section{Teknik Analisis Data}

1. Uji Instrumen Penelitian

a. Uji Validitas

Valid berarti instrument tersebut dapat digunakan untuk mengukur apa yang seharusnya diukur. Dalam penelitian ini, pengujian validitas menggunakan bantuan komputer melalui program SPSS V. 12 for windows.

b. Uji Reliabilitas

Suatu pertanyaan/pernyataan dikatakan reliabel atau handal jika jawaban responden terhadap pertanyaan/pernyataan tersebut adalah konsisten atau stabil dari waktu ke waktu.

Suatu konstruk atau variabel dikatakan reliabel jika nilai Cronbach Alpha lebih besar dari 0,60 .

c. Uji Linieritas

Linieritas merupakan salah satu asumsi dari analisis regresi. Maksudnya adalah apakah garis regresi antara $\mathrm{x}$ dan $\mathrm{y}$ membentuk garis linier atau tidak. Kalau tidak linier, maka analisis regresi tidak dapat dilanjutkan. Apabila F hitung $<\mathrm{F}$ tabel, maka analisis regresi dapat dilanjutkan. Tetapi apabila $\mathrm{F}$ hitung > F tabel, berarti analisis regresi tidak dapat dilanjutkan.

2. Pengujian Hipotesa

a. Analisis Regresi Jalur (Path Regression Analysis)

Analisis jalur dilakukan dengan menggunakan korelasi dan regresi, sehingga dapat diketahui untuk sampai pada dependen terakhir, harus lewat jalur langsung atau melalui variabel intervening atau variabel antara. 
Analisis ini juga digunakan untuk mengetahui pengaruh antara variabel bebas terhadap variabel terikat, dan variabel bebas terhadap variabel antara serta korelasi antar variabel bebas. Adapun persamaan yang digunakan adalah :

1) Persamaan Pertama

$$
\mathrm{Y}_{1}=\mathrm{b}_{1} \mathrm{X}_{1}+\mathrm{b}_{2} \mathrm{X}_{2}+\mathrm{e}_{1}
$$

Keterangan :

$$
\begin{array}{ll}
\mathrm{Y}_{1} & =\text { Motivasi } \\
\mathrm{b}_{1}, \mathrm{~b}_{2} & =\text { koefisien regresi } \\
\mathrm{X}_{1} & =\text { Komunikasi } \\
\mathrm{X}_{2} & =\text { Lingkungan kerja } \\
\mathrm{e}_{1} & =\text { error }
\end{array}
$$

2) Persamaan Kedua

$$
Y_{2}=b_{3} X_{1}+b_{4} X_{2}+b_{5} X_{3}+e_{2}
$$

Keterangan :

$$
\begin{array}{ll}
\mathrm{Y}_{2} & =\text { Kinerja } \\
\mathrm{b}_{3}, \mathrm{~b}_{4}, \mathrm{~b}_{5}=\text { koefisien regresi } & =\text { Komunikasi } \\
\mathrm{X}_{1} & =\text { Lingkungan kerja } \\
\mathrm{X}_{2} & =\text { Motivasi } \\
\mathrm{X}_{3} & =\text { error }
\end{array}
$$

a. Uji F

Uji F digunakan untuk mengetahui pengaruh signifikan secara simultan atau serempak antara variabel independen terhadap variabel dependen. Dalam penelitian ini, uji F menggunakan bantuan komputer melalui program SPSS V. 17.0 for windows. Apabila signifikansi $<0,05$ berarti ada pengaruh yang signifikan secara simultan atau serempak antara variabel independen dengan variable dependen.

b. Koefisien Determinasi $\left(\mathrm{R}^{2}\right)$

$$
\text { Koefisien determinasi pada }
$$
intinya mengukur seberapa jauh kemampuan model dalam menerangkan variasi variabel dependen. Penetapan determinasi dalam analisis jalur dilakukan dengan melihat besarnya varian yang dilambangkan dengan $e$.
Tingkat ketepatan regresi ditunjukan oleh $\mathrm{R}^{2}$ yang besarnya berkisar antara $0 \leq \mathrm{R}^{2} \leq 1$, semakin besar nilai $\mathrm{R}^{2}$ berarti makin tepat suatu garis regresi linier yang digunakan sebagai pendekatan, dan apabila nilai $\mathrm{R}^{2}$ sama dengan 1 maka pendekatan itu benar-benar sempurna.

c. Uji t

Uji $\mathrm{t}$ ini digunakan untuk menguji pengaruh antara masingmasing variabel independen dengan variabel dependen. Dalam penelitian ini, uji $t$ menggunakan bantuan komputer melalui program SPSS V. 17.0 for windows. Apabila signifikansi $<0,05$ berarti ada pengaruh yang signifikan antara masing-masing variabel independen dengan variable dependen.

e. Pengaruh Langsung dan Tidak Langsung, Total Effect

Pengaruh langsung adalah pengaruh dari satu variabel independen ke variabel dependen, tanpa melalui variabel intervening. Sedangkan pengaruh tidak langsung adalah pengaruh dari variabel independen ke variabel dependen melalui variabel intervening.

f. Korelasi

Korelasi merupakan uji yang dilakukan untuk mengetahui masingmasing hubungan antar variabel independen dan dependen, korelasi akan dilakukan dengan uji Pearson. Analisis korelasi dihitung untuk persamaan stuktur 1 dan persamaan struktur 2, serta menghitung kuat lemahnya korelasi (r). Interprestasi koefisien korelasi nilai $\mathrm{r}$ adalah sebagai berikut : 


\begin{tabular}{|c|l|}
\hline Koefisien Korelasi & \multicolumn{1}{|c|}{ Penafsiran } \\
\hline $0 \mathrm{~s} / \mathrm{d} 0,25$ & Korelasi sangat lemah \\
$>0,25 \mathrm{~s} / \mathrm{d} 0,50$ & Korelasi cukup kuat \\
$>0,50 \mathrm{~s} / \mathrm{d} 0,75$ & Korelasi kuat \\
$>0,75 \mathrm{~s} / \mathrm{d} 1$ & Korelasi sangat kuat \\
\hline
\end{tabular}

\section{HASIL DAN PEMBAHASAN}

1. Gambaran Umum Obyek Penelitian

a. Berdasarkan kategori jenis kelamin menunjukkan bahwa sebagian besar responden adalah laki-laki dengan jumlah 17 orang atau 51,52\%, sedangkan jumlah perempuan 16 orang atau 48,48\%. Dari komposisi tersebut nampak bahwa sebagian besar pegawai yang menjadi responden adalah laki-laki.

b. Berdasarkan kategori tingkat pendidikan menunjukkan bahwa responden yang mempunyai tingkat pendidikan SLTA sebanyak 1 orang atau 3,03\%, Diploma-3 sebanyak 1 orang atau 3,03\%, S1 sebanyak 19 orang atau $57,57 \%$ dan S2 sebanyak 12 orang $36,37 \%$.

c. Berdasarkan kategori usia menunjukkan bahwa usia responden yang berada pada usia antara $20 \mathrm{~s} / \mathrm{d} 29$ tahun sebanyak 1 orang atau 3,03\%, usia antara $30 \mathrm{~s} / \mathrm{d} 39$ tahun sebanyak 11 orang atau $33,33 \%$, usia antara 40 s/d 49 tahun sebanyak 17 orang atau $51,52 \%$ dan usia lebih dari 50 tahun sebanyak 4 orang atau $12,21 \%$.

2. Hasil Dan Analisis
a. Uji Instrumen Penelitian

1) Uji Validitas

Uji Validitas digunakan untuk mengukur sah atau tidaknya butir pernyataan yang diajukan. Suatu pernyataan dikatakan valid atau sah jika pernyataan tersebut mampu mengungkapkan sesuatu yang akan diukur.

a) Variabel Kinerja terdiri dari 5 item pernyataan. Pengujian validitas menggunakan teknik one shot methods yaitu dengan membandingkan nilai $\mathrm{r}$ hitung dengan $r$ tabel dan didapatkan hasil bahwa dari 5 item pernyataan semua valid

b) Variabel Motivasi terdiri dari 5 item pernyataan. didapatkan hasil bahwa dari 5 item pernyataan semua valid

c) Variabel Komunikasi terdiri dari 5 item pernyataan. didapatkan hasil bahwa dari 5 item pernyataan semua valid

d) Variabel Lingkungan Kerja terdiri dari 5 item pernyataan. didapatkan hasil bahwa dari 5 item pernyataan semua valid

2) Uji Reliabilitas

Suatu konstruk dikatakan reliabel jika memberikan nilai Cronbach Alpha > 0,6. Pengujian reliabilitas menggunakan bantuan computer program SPSS for windows dengan hasil sebagai berikut :

\begin{tabular}{|l|c|c|c|}
\hline \multicolumn{1}{|c|}{ Variabel } & $\begin{array}{c}\text { Alpha } \\
\text { Cronbach }\end{array}$ & Kriteria & Keterangan \\
\hline Kinerja & 0,743 & Alpha Cronbach & Reliabel \\
Motivasi & 0,725 & $>0,6$ & Reliabel \\
Komunikasi & 0,693 & & Reliabel \\
Lingkungan Kerja & 0,776 & & Reliabel \\
\hline
\end{tabular}


Table diatas menunjukkan bahwa jawaban seseorang dari masingmasing variable adalah konsisten, sehingga dikatakan bahwa pernyataan dari masing-masing variabel adalah reliabel.

\section{3) Uji Linieritas}

Dari hasil uji linieritas menunjukkan nilai $\mathrm{R}^{2}$ sebesar 0,001 dengan jumlah sample 33, besarnya nilai $\mathrm{c}^{2}$ hitung $=33 \mathrm{x}$ $0,001=0,033$, sedangkan nilai $\mathrm{c}^{2}$ tabel sebesar 43,78. Karena niilai $\mathrm{c}^{2}$ hitung lebih kecil dari $\mathrm{c}^{2}$ tabel maka dapat disimpulkan bahwa model yang benar adalah model linier.

b. Uji Hipotesis

1) Analisa Regresi Jalur

Persamaan Pertama

$\mathrm{Y}_{1}=0,517 \mathrm{X}_{1}+0,370 \mathrm{X}_{2}+\mathrm{e}_{1}$

Sig $(0,003)^{* *} \quad(0,025)^{* *}$

Dari hasil pengujian persamaan pertama tersebut dapat diartikan sebagai berikut :

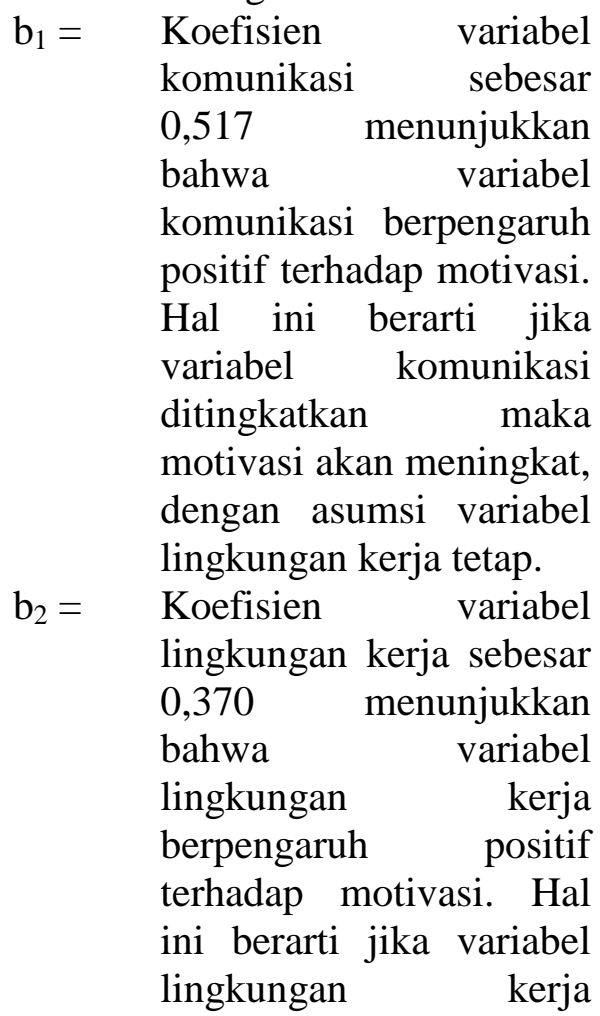

ditingkatkan maka motivasi akan meningkat, dengan asumsi variabel komunikasi tetap.

Persamaan kedua

$\mathrm{Y}_{2}=0,326 \mathrm{X}_{1}+0,335 \mathrm{X}_{2}+$ $0,344 X_{3}+e_{2}$

$\begin{array}{lll}\text { Sig } & (0,015)^{* *} \quad(0,008)^{* *}\end{array}$

Dari hasil pengujian persamaan kedua tersebut dapat diartikan sebagai berikut :

$\mathrm{b}_{1}=$ Koefisien variabel komunikasi sebesar 0,326 menunjukkan bahwa variabel komunikasi berpengaruh positif terhadap kinerja. Hal ini berarti jika variabel komunikasi ditingkatkan maka kinerja akan meningkat, dengan asumsi variabel lingkungan kerja dan motivasi tetap.

$\mathrm{b}_{2}=$ Koefisien variabel lingkungan kerja sebesar 0,335 menunjukkan bahwa variabel lingkungan kerja berpengaruh positif terhadap kinerja. Hal ini berarti jika variabel lingkungan kerja ditingkatkan maka kinerja akan meningkat, dengan asumsi variabel komunikasi dan motivasi tetap.

$\mathrm{b}_{3}=\quad$ Koefisien variabel motivasi sebesar 0,344 menunjukkan bahwa variabel motivasi berpengaruh positif terhadap kinerja. Hal ini berarti jika variabel motivasi ditingkatkan maka kinerja akan 
2) Uji F

$$
\begin{array}{lr}
\text { meningkat, } & \text { dengan } \\
\text { asumsi } & \text { variabel } \\
\text { komunikasi } & \text { dan } \\
\text { lingkungan kerja tetap. }
\end{array}
$$

Dari hasil uji $F$ dapat diketahui besarnya $\mathrm{F}$ hitung adalah 60,022 dengan signifikansi sebesar 0,000 atau lebih kecil dari 0,05 , sehingga dapat disimpulkan bahwa secara simultan atau bersama-sama variabel bebas yaitu komunikasi, lingkungan kerja dan motivasi berpengaruh signifikan terhadap variabel terikat yaitu kinerja.

3) Uji Koefisien Determinasi $\left(\mathrm{R}^{2}\right)$
a) Koefisien
Determinasi
Persamaan I
Dari hasil olah data persamaan pertama di atas diketahui $\mathrm{R}_{1}^{2}$ sebesar 0,698.
$\mathrm{e}_{1}=\sqrt{\mathrm{E}} 1-\mathrm{R}_{1}^{2}$
$\mathrm{e}_{1}=\sqrt{\mathrm{E}} 1-0,698$
$\mathrm{e}_{1}=0,550$
Dari perhitungan nilai $\mathrm{e}_{1}$ pada persamaan pertama diperoleh hasil sebesar 0,550 .
b) Koefisien Determinasi
Persamaan II
Dari hasil olah data persamaan kedua di atas diketahui $\mathrm{R}_{2}^{2}$ sebesar 0,861 .
$\mathrm{e}_{2}=\sqrt{\mathrm{E}} 1-\mathrm{R}_{2}^{2}$
$\mathrm{e}_{2}=\sqrt{\mathrm{E}} 1-0,861$
$\mathrm{e}_{2}=0,373$
Dari perhitungan nilai $\mathrm{e}_{2}$ pada persamaan kedua diperoleh hasil sebesar 0,373.
c) Koefisien Determinasi Total

$$
\begin{aligned}
\mathrm{R}^{2} \text { model }=1 & -\left(\left(\mathrm{e}_{1}\right)^{2} \times\left(\mathrm{e}_{2}\right)^{2}\right) \\
& =1-(0,302 \mathrm{x} \\
& 0,139) \\
& =1-0,441 \\
& =0,559
\end{aligned}
$$$$
(55,9 \%)
$$

Berdasarkan hasil perhitungan diatas dapat diketahui bahwa variabel kinerja pegawai Badan Perencanaan Pembangunan daerah Kabupaten Sukoharjo dijelaskan oleh variabel komunikasi, lingkungan kerja dengan motivasi sebagai variabel intervening sebesar $55,9 \%$, sisanya sebesar $44,1 \%$ dijelaskan variabel lain diluar model, seperti kepemimpinan, disiplin kerja, kepuasan kerja dan sebagainya.

4) Uji t

a) Persamaan $I$

(1) Hipotesis 1

Dari hasil uji t persamaan pertama dapat dilihat bahwa nilai signifikansi untuk komunikasi sebesar $0,003<0,05$, berarti bahwa komunikasi berpengaruh positif dan signifikan terhadap motivasi pegawai Badan

Perencanaan

Pembangunan Daerah Kabupaten Sukoharjo.

(2) Hipotesis 2

Dari hasil uji t persamaan pertama dapat dilihat bahwa nilai signifikansi untuk lingkungan kerja sebesar $0,025<0,05$, berarti bahwa lingkungan kerja berpengaruh positif dan signifikan terhadap motivasi pegawai Badan Perencanaan Pembangunan Daerah Kabupaten Sukoharjo.

b) Persamaan II

(1) Hipotesis 3 
Dari hasil uji t persamaan kedua dapat dilihat bahwa nilai signifikansi untuk komunikasi sebesar $0,015<0,05$, berarti bahwa komunikasi berpengaruh positif dan signifikan terhadap kinerja pegawai Badan Perencanaan Pembangunan Daerah Kabupaten Sukoharjo.

(2) Hipotesis 4

Dari hasil uji t persamaan kedua dapat dilihat bahwa nilai signifikansi untuk lingkungan kerja sebesar $0,008<0,05$, berarti bahwa lingkungan kerja berpengaruh positif dan signifikan terhadap kinerja pegawai Badan Perencanaan

Pembangunan Daerah Kabupaten Sukoharjo.

(3) Hipotesis 5
Dari hasil uji t persamaan kedua dapat dilihat bahwa nilai signifikansi untuk motivasi sebesar $0,010<0,05$, berarti bahwa motivasi berpengaruh positif dan signifikan terhadap kinerja pegawai Badan Perencanaan

Pembangunan Daerah Kabupaten Sukoharjo.

5) Pengaruh Langsung, Tidak Langsung dan Pengaruh Total

Pengaruh langsung adalah pengaruh dari suatu variabel bebas ke variabel terikat tanpa melalui variabel bebas lainnya. Pengaruh tidak langsung adalah pengaruh dari suatu variabelbebas ke variabel terikat melalui variabel bebas lainnya atau variabel intervening. Sedangkan hasil penjumlahan pengaruh langsung dan pengaruh tidak langsung disebut pengaruh total.

\begin{tabular}{|l|c|c|c|}
\hline \multicolumn{1}{|c|}{ Hubungan } & $\begin{array}{c}\text { Pengaruh } \\
\text { Langsung }\end{array}$ & $\begin{array}{c}\text { Pengaruh } \\
\text { Tidak } \\
\text { Langsung }\end{array}$ & Pengaruh Total \\
\hline $\begin{array}{l}\text { Komunikasi } \rightarrow \\
\text { Kinerja }\end{array}$ & 0,326 & & \\
\hline $\begin{array}{l}\text { Komunikasi } \rightarrow \\
\text { Motivasi } \rightarrow \text { Kinerja }\end{array}$ & & $\begin{array}{c}0,517 \times 0,344 \\
=0,178\end{array}$ & $0,326+0,178=0,504$ \\
\hline $\begin{array}{l}\text { Lingkungan Kerja } \\
\rightarrow \quad \text { Kinerja }\end{array}$ & 0,335 & $0,370 \times 0,344$ \\
$=0,127$ & $0,335+0,127=0,462$ \\
\hline $\begin{array}{l}\text { Lingkungan Kerja } \\
\rightarrow \text { Motivasi }\end{array}$ & & \begin{tabular}{c} 
Kinerja \\
\hline
\end{tabular}
\end{tabular}

Sumber : Data diolah, 2015

a) Pengaruh Langsung

(1) Komunikasi terhadap kinerja

Berdasarkan tablediatas

diketahui bahwa komunikasi

berpengaruh positif terhadap

kinerja dengan koefisien

sebesar 0,326.
(2) Lingkungan kerja terhadap kinerja Berdasarkan table diatas diketahui bahwa lingkungan kerja berpengaruh positif terhadap kinerja dengan koefisien sebesar 0,335. 
Berdasarkan pengaruh langsung diatas diketahui bahwa lingkungan kerja secara langsung lebih berpengaruh terhadap kinerja daripada komunikasi.

b) Pengaruh Tidak Langsung

(1) Komunikasi terhadap kinerja melalui motivasi

Berdasarkan table di atas diketahui pengaruh tidak langsung komunikasi terhadap kinerja melalui motivasi sebesar 0,178

(2) Lingkungan kerja terhadap kinerja melalui motivasi

Berdasarkan table di atas diketahui pengaruh tidak langsung lingkungan kerja terhadap kinerja melalui motivasi sebesar 0,127

(3) Kesimpulan analisis jalur

(a) Pengaruh langsung komunikasi terhadap kinerja sebesar 0,326, pengaruh tidak langsung komunikasi terhadap kinerja melalui motivasi sebesar 0,178, maka jalur langsung lebih dominan daripada jalur tidak langsung, dengan demikian motivasi memediasi hubungan antara komunikasi dengan kinerja tetapi tidak efektif.

(b) Pengaruh langsung lingkungan kerja terhadap kinerja sebesar 0,335 , pengaruh tidak langsung lingkungan kerja terhadap kinerja melalui motivasi sebesar 0,127, maka jalur langsung lebih dominan daripada jalur tidak langsung, dengan demikian motivasi memediasi hubungan antara lingkungan kerja dengan kinerja tetapi tidak efektif.

c) Pengaruh Total

(1) Pengaruh total komunikasi terhadap kinerja melalui motivasi sebesar 0,504.

(2) Pengaruh total lingkungan kerja terhadap kinerja melalui motivasi sebesar 0,462 .

Dilihat dari pengaruh total untuk meningkatkan kinerja lebih efektif melalui komunikasi terhadap kinerja melalui motivasi daripada lingkungan kerja terhadap kinerja melalui motivasi.

6) Uji Korelasi

Uji korelasi dilakukan untuk mengetahui besarnya koefisien korelasi antara variabel bebas dengan variabel terikat. Dari olah data menggunakan program SPSS for windows diperoleh hasil sebagai berikut : 


\begin{tabular}{|c|c|c|c|c|c|}
\hline \multicolumn{6}{|c|}{ Correlations } \\
\hline & & Kinerja & Motivasi & Komunikasi & $\begin{array}{c}\text { Lingkungan } \\
\text { Kerja }\end{array}$ \\
\hline \multirow[t]{3}{*}{ Kinerja } & Pearson Correlation & 1 &, $862^{\star *}$ & $859^{\star *}$ & $8,849^{\star \star}$ \\
\hline & Sig. (2-tailed) & &, 000 &, 000 &, 000 \\
\hline & $\mathrm{N}$ & 33 & 33 & 33 & 33 \\
\hline \multirow{3}{*}{ Motivasi } & Pearson Correlation &, $862^{* *}$ & 1 & $801^{* *}$ &, $767^{\star *}$ \\
\hline & Sig. (2-tailed) &, 000 & &, 000 &, 000 \\
\hline & $\mathrm{N}$ & 33 & 33 & 33 & 33 \\
\hline \multirow[t]{3}{*}{ Komunikasi } & Pearson Correlation & $859 * *$ & $801^{* *}$ & 1 & ,768** \\
\hline & Sig. (2-tailed) &, 000 &, 000 & & 000 \\
\hline & $\mathrm{N}$ & 33 & 33 & 33 & 33 \\
\hline \multirow[t]{3}{*}{ Lingkungan Kerja } & Pearson Correlation & $849 * *$ &, $767^{\star *}$ &, $768^{* *}$ & 1 \\
\hline & Sig. (2-tailed) & 000 &, 000 &, 000 & \\
\hline & $\mathrm{N}$ & 33 & 33 & 33 & 33 \\
\hline
\end{tabular}

${ }^{* *}$. Correlation is significant at the 0.01 level (2-tailed).

Sumber : Data yang diolah, 2015

Dari table diatas dapat

diketahui hubungan atau korelasi antar variable sebagai berikut :

a) Variabel komunikasi berkorelasi terhadap variabel motivasi sebesar 0,801 dan sig $=0,000$ yang artinya terdapat hubungan yang sangat kuat dan signifikan.

b) Variabel lingkungan kerja berkorelasi terhadap variabel motivasi sebesar 0,767 dan sig $=$ 0,000 yang artinya terdapat hubungan yang sangat kuat dan signifikan.

c) Variabel komunikasi berkorelasi terhadap variabel kinerja sebesar 0,859 dan sig $=0,000$ yang artinya terdapat hubungan yang sangat kuat dan signifikan.

d) Variabel lingkungan kerja berkorelasi terhadap variabel kinerja sebesar 0,849 dan sig $=$ 0,000 yang artinya terdapat hubungan yang sangat kuat dan signifikan.

e) Variabel motivasi berkorelasi terhadap variabel kinerja sebesar 0,862 dan sig $=0,000$ yang artinya terdapat hubungan yang sangat kuat dan signifikan.

Secara lengkap hasil analisis jalur dalam penelitian ini dapat dijelaskan secara rinci pada gambar berikut : 


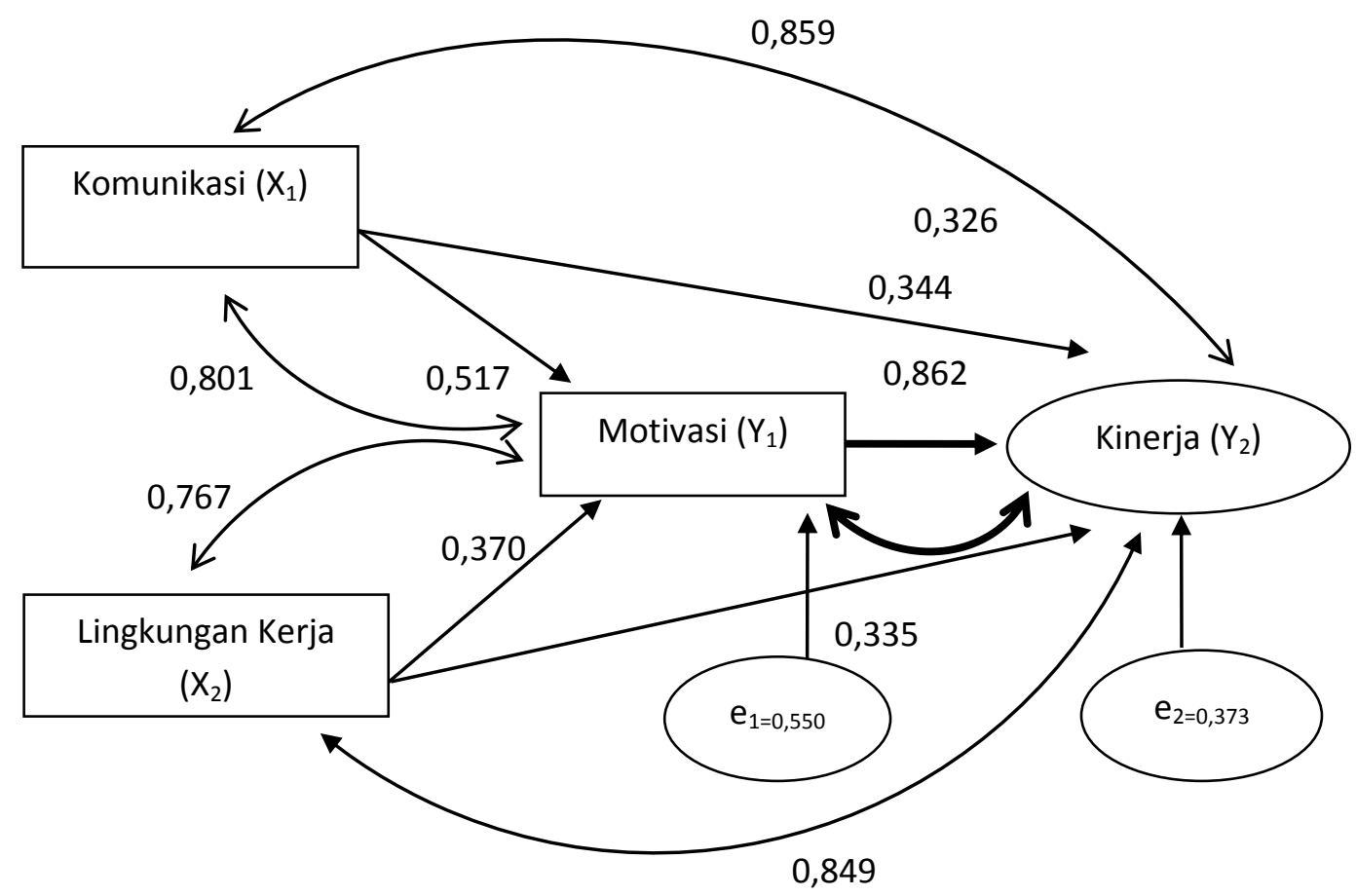

Analisis Jalur Path

\section{Implikasi Manajerial}

Berdasarkan hasil pengujian hipotesis tersebut di atas maka dapat diterapkan hal-hal berikut :

a. Komunikasi berpengaruh terhadap motivasi pegawai Badan Perencanaan Pembangunan Daerah Kabupaten Sukoharjo.

Komunikasi yang lancar antar pegawai akan memberikan motivasi kepada pegawai untuk bekerja. Sebagai contoh jika selalu terjadi miss komunikasi akan menyebabkan pegawai salah dalam melakukan pekerjaan, pegawai menyelesaikan pekerjaan yang seharusnya bukan menjadi tanggung jawabnya. Hal ini membuat pegawai saling menyalahkan yang akan menyebakan permusuhan atau perselisihan antar pegawai sehingga membuat pegawai malas bekerja. b. Lingkungan kerja berpengaruh terhadap motivasi pegawai Badan Perencanaan Pembangunan Daerah Kabupaten Sukoharjo.

Lingkungan kerja yang nyaman akan meningkatkan motivasi pegawai untuk bekerja. Jika ruang kerja kotor, bising, udara terasa panas dan kurangnya pencahayaan akan membuat pegawai tidak tahan lama berada di dalam ruang kerja, mereka lebih memilih keluar kantor disaat jam kerja sehingga pekerjaan tidak bisa diselesaikan tepat waktu.

c. Komunikasi berpengaruh terhadap kinerja pegawai Badan Perencanaan Pembangunan Daerah Kabupaten Sukoharjo.

Kinerja pegawai Badan Perencanaan Pembangunan Daerah Kabupaten Sukoharjo akan meningkat apabila jalur komunikasi lancar sehingga 
koordinasi antar bidang bisa berjalan dengan baik dan tidak ada saling lempar tanggung jawab. Atasan dalam memberikan instruksi harus jelas dan mudah dipahami sehingga bawahan dalam melaksanakan tugasnya tidak menyalahi aturan yang ada dan sesuai dengan apa yang diharapkan oleh atasan.

d. Lingkungan kerja berpengaruh terhadap kinerja pegawai Badan Perencanaan Pembangunan Daerah Kabupaten Sukoharjo.

Lingkungan kerja yang ada bisa meningkatkan kinerja pegawai, untuk itu perlu adanya peningkatan kualitas lingkungan kerja di Badan Perencanaan Pembangunan Daerah Kabupaten Sukoharjo, seperti penataan dokumen yang lebih rapi dengan adanya almari arsip yang disediakan disetiap ruangan untuk dokumen selama tahun anggaran berjalan dan disediakan ruangan khusus dokumen atau arsip yang sudah lewat tahun anggaran sehingga meja kerja dan ruangan kerja terlihat lebih bersih dan rapi.

e. Motivasi berpengaruh terhadap kinerja pegawai Badan Perencanaan Pembangunan Daerah Kabupaten Sukoharjo melalui motivasi.

Motivasi sangat diperlukan untuk meningkatkan kinerja pegawai. Motivasi yang diberikan oleh seorang pimpinan seperti adanya kesempatan untuk menduduki jabatan tertentu membuat pegawai dalam bekerja akan menunjukkan prestasi yang sebaik-baiknya, untuk itu pimpinan harus mampu memberikan jaminan kesempatan promosi jabatan yang sama terhadap semua pegawai sesuai dengan kinerjanya dan bukan karena pilih kasih, dan juga pemimpin memberikan kesempatan kepada pegawai untuk mengikuti pelatihan yang sesuai dengan bidangnya untuk meningkatkan kemampuan dirinya.

\section{KESIMPULAN DAN SARAN \\ Kesimpulan}

1. Komunikasi berpengaruh positif dan signifikan terhadap motivasi pegawai Badan Perencanaan Pembangunan Daerah Kabupaten Sukoharjo.

Dari hasil analisis jalur pada persamaan pertama diperoleh nilai koefisien variabel komunikasi sebesar 0,517, dan dari uji t persamaan pertama nilai signifikansi untuk komunikasi sebesar $0,003<0,05, \quad$ berarti komunikasi berpengaruh positif dan signifikan terhadap motivasi pegawai Badan Perencanaan Pembangunan Daerah Kabupaten Sukoharjo. Dengan demikian hipotesis 1 terbukti.

2. Lingkungan kerja berpengaruh positif dan signifikan terhadap motivasi pegawai Badan Perencanaan Pembangunan Daerah Kabupaten Sukoharjo.

Dari hasil analisis jalur pada persamaan pertama diperoleh nilai koefisien variabel lingkungan kerja sebesar 0,370, dan dari uji t persamaan pertama nilai signifikansi untuk komunikasi sebesar $0,025<0,05$, berarti lingkungan kerja berpengaruh positif dan signifikan terhadap motivasi pegawai Badan Perencanaan Pembangunan Daerah Kabupaten Sukoharjo. Dengan demikian hipotesis 2 terbukti.

3. Komunikasi berpengaruh positif dan signifikan terhadap kinerja pegawai 
Badan Perencanaan Pembangunan Daerah Kabupaten Sukoharjo.

Dari hasil analisis jalur pada persamaan kedua diperoleh nilai koefisien variabel komunikasi sebesar 0,326, dan dari uji t persamaan kedua nilai signifikansi untuk komunikasi sebesar $0,015<0,05$, berarti komunikasi berpengaruh positif dan signifikan terhadap kinerja pegawai Badan Perencanaan Pembangunan Daerah Kabupaten Sukoharjo. Dengan demikian hipotesis 3 terbukti.

4. Lingkungan kerja berpengaruh positif dan signifikan terhadap kinerja pegawai Badan Perencanaan Pembangunan Daerah Kabupaten Sukoharjo.

Dari hasil analisis jalur pada persamaan kedua diperoleh nilai koefisien variabel lingkungan kerja sebesar 0,335, dan dari uji t persamaan kedua nilai signifikansi untuk komunikasi sebesar $0,008<0,05$, berarti lingkungan kerja berpengaruh positif dan signifikan terhadap kinerja pegawai Badan Perencanaan Pembangunan Daerah Kabupaten Sukoharjo. Dengan demikian hipotesis 4 terbukti.

5. Motivasi berpengaruh positif dan signifikan terhadap kinerja pegawai Badan Perencanaan Pembangunan Daerah Kabupaten Sukoharjo.

Dari hasil analisis jalur pada persamaan kedua diperoleh nilai koefisien variabel motivasi sebesar 0,344, dan dari uji t persamaan kedua nilai signifikansi untuk komunikasi sebesar $0,010<0,05$, berarti motivasi berpengaruh positif dan signifikan terhadap kinerja pegawai Badan Perencanaan Pembangunan Daerah Kabupaten Sukoharjo. Dengan demikian hipotesis 5 terbukti.

6. Dari tiga variabel yaitu komunikasi, lingkungan kerja dan motivasi yang paling berpengaruh dan mempunyai hubungan paling kuat dengan kinerja adalah motivasi.

\section{Saran}

1. Untuk meningkatkan kinerja pegawai Badan Perencanaan Pembangunan Daerah Kabupaten Sukoharjo motivasi memegang peranan yang sangat penting, untuk itu pimpinan harus selalu memberikan motivasi pada pegawai dengan memperhatikan kecukupan gaji dan tunjangan untuk memenuhi kebutuhan keluarga pegawai, memberikan kesempatan pegawai untuk mengembangkan kemampuan dirinya, memberikan penghargaan kepada pegawai yang berprestasi dan memberikan kesempatan pegawai untuk mendapatkan promosi jabatan sehingga mereka mau bekerja lebih giat dan dapat menyelesaikan tugasnya tepat waktu.

2. Komunikasi perlu ditingkatkan dan dikembangkan agar menjadi lebih lancar dan efektif sehingga kinerja menjadi lebih baik dengan cara memberikan perintah yang jelas, tepat waktu dan ditujukan kepada pegawai yang tepat sesuai dengan tugas dan tanggung jawabnya.

3. Menciptakan lingkungan kerja yang nyaman dengan cara menyimpan dokumen pada tempatnya, setiap ruangan di pasang air conditioner, segera mengganti lampu yang sudah tidak menyala dan membatasi penggunaan audio di dalam ruang kerja agar tidak bising. 


\section{DAFTAR PUSTAKA}

Gibson JL. Ivancevich JM,Donnely Jr. JH. 2003. Organization, 8 th ed, , Boston Massachusetts: Irwan, Inc.

Hasibuan Malayu S.P. 2003. Organisasi dan Motivasi Dasar Peningkatan Produktivitas, Cetakan keempat, Jakarta: PT Bumi Aksara

Hasibuan Malayu S.P. 2007. Manajemen Sumber Daya Manusia, Edisi Revisi, Cetakan Keenam, Jakarta: Penerbit Bumi Aksara

Mahsun Mohamad. 2006. Pengukuran Kinerja Sektor Publik, Yogyakarta: BPFE

Mangkunegara Anwar Prabu. 2004. Manajemen Sumber Daya Manusia, Jakarta: Salemba Empat

Mangkunegara Anwar Prabu. 2006. Perilaku dan Budaya Organisasi, Cetakan Pertama, Bandung: PT. Refika Aditama

Mangkunegara Anwar Prabu. 2005. Perilaku dan Kepuasan Kerja, Cetakan Pertama, Bandung: PT. Refika Aditama

Sadili Samsudin. 2006. Manajemen Sumber daya Manusia, Bandung: Pustaka Setia

Sedarmayanti. 2003. Sumber Daya Manusia dan Produktivitas Kerja, Bandung: Mandor Maju

Sedarmayanti. 2008. Manajemen Sumber Daya Manusia, Bandung: PT. Revika Aditama

http://www.muhamadnurdinyusuf.wordpress .com, Jurnal Sumber Daya Manusia 